Nafta-Gaz 2019, no. 12, pp. 751-758, DOI: 10.18668/NG.2019.12.03

\title{
New shale hydration inhibitors adapted to the downhole conditions
}

\author{
Nowe inhibitory hydratacji skał ilastych dostosowane do warunków otworowych
}

\author{
Grzegorz Zima \\ Oil and Gas Institute - National Research Institute
}

\begin{abstract}
The subject of the paper is the application of polyol compounds as active shale formation hydration inhibitors in drilling muds as the result of permanent interest from the industry in the use of this type drilling mud systems. Due to opportunity of precise compounds selection ensuring optimum properties of the drilling mud under specific down hole conditions, new agents have been developed that work effectively in a wider temperature range experienced in borehole conditions. The paper describes laboratory research carried over polyols that haven't been used in drilling fluids technology yet but may ensure optimal inhibition properties in the wide temperature range. Compounds belongs to polyglycols category like ethylene oxide or copolymers of ethylene oxide and propylene oxide with different molecular weight, are widely use so far. However, in the presented discussion other agents were used, which are products of ethoxylation and propoxylation of long-chain hydrocarbon fatty alcohols (10 and more carbon atoms). The main test that can prove drilling mud inhibitory properties is active shale dispersion investigation, routinely carried in ambient conditions. As part of the additional tests carried out, the influence of the inhibitors used on the active shale dispersion under elevated temperature conditions was determined in order to confirm the inhibitory properties of these agents in near-down hole conditions. Near down hole conditions test was also carried out on drilling muds containing polyols group compounds, ie resistance test to contamination with ions of divalent metals $\left(\mathrm{Ca}^{2+}\right.$ and $\left.\mathrm{Mg}^{2+}\right)$, solid phase contamination (milled Miocene shale pretending drill cuttings) and increased temperature. Investigations were also carried out on clouding of polyol solutions in $7 \% \mathrm{KCl}$ solution. The acquired results indicate that chemical compound presence of the hydrophobic chain derived from fatty alcohol in the molecule further increases the effectiveness of the rock hydration inhibitor. The results obtained during the study allowed for a better understanding of the inhibition mechanism of these agents on the active shale. The new rock hydration inhibitor developed as part of the work can be used in industrial conditions.
\end{abstract}

Key words: drilling mud, hydration inhibitor, polyglycol, polyol, shale.

STRESZCZENIE: Przedstawiona w artykule tematyka dotyczy zastosowania w płuczkach wiertniczych związków z grupy polioli jako inhibitorów hydratacji skał ilastych i jest wynikiem ciągłego zainteresowania ze strony przemysłu wykorzystaniem tego typu płuczek. Ze względu na możliwość bardziej precyzyjnego doboru związków zapewniających optymalne właściwości płuczki w określonych warunkach otworowych - opracowano nowe środki działające efektywnie w szerszym zakresie temperatur występujących w warunkach otworowych. W niniejszym artykule opisano badania laboratoryjne nad doborem dotychczas niestosowanych w technologii płuczkowej polioli, które zapewnią uzyskanie optymalnych właściwości inhibicyjnych płuczek wiertniczych w szerokim zakresie temperatury. Dotychczas wykorzystywane środki z tej grupy to tzw. poliglikole, będące polimerami tlenku etylenu lub kopolimerami tlenku etylenu i tlenku propylenu, różniące się masą cząsteczkową. Natomiast w przedstawionych badaniach użyto dodatkowo innych środków, które są produktami etoksylowania i propoksylowania alkoholi o długich łańcuchach węglowodorowych (10 i więcej atomów węgla). Głównym badaniem potwierdzającym inhibicyjne właściwości płuczek jest badanie dyspersji skały ilastej, standardowo przeprowadzane w warunkach otoczenia. W ramach wykonanych dodatkowo badań określono wpływ użytych inhibitorów na dyspersję skały ilastej w warunkach podwyższonej temperatury celem potwierdzenia właściwości inhibicyjnych tych środków w warunkach zbliżonych do otworowych. Przeprowadzono również badania płuczek zawierających związki z grupy polioli w warunkach otworopodobnych, tj. wykonano badania odporności tych płuczek na skażenie jonami metali dwuwartościowych $\left(\mathrm{Ca}^{2+} \mathrm{i} \mathrm{Mg} \mathrm{Mg}^{2+}\right)$, skażenie fazą stałą (zmielonym łupkiem mioceńskim, imitującym zwierciny) oraz działanie podwyższonej temperatury. Wykonano również badania temperatury mętnienia roztworów polioli w 7-procentowym roztworze $\mathrm{KCl}$. Uzyskane wyniki badań wskazują, że obecność w cząsteczce związku chemicznego łańcucha hydrofobowego pochodzącego od alkoholu tłuszczowego dodatkowo zwiększa efektywność działania inhibitora hydratacji skał. Wyniki otrzymane podczas badań pozwoliły na lepsze zrozumienie mechanizmu inhibicyjnego działania tych środków na skały ilaste. Opracowany w ramach pracy nowy inhibitor hydratacji skał może znaleźć zastosowanie w warunkach przemysłowych.

Słowa kluczowe: płuczka wiertnicza, inhibitor hydratacji, poliglikol, poliol, łupek ilasty.

Corresponding author: G. Zima, e-mail: grzegorz.zima@inig.pl

Article contributed to the Editor 11.01.2019. Approved for publication 06.11.2019 


\section{Introduction}

Glycol - potassium and triple - inhibited drilling muds are currently one of the most commonly used in industrial conditions in the country. The component of both above mentioned drilling mud systems that controls inhibition properties is polyols-type compound. Polyglycols are type of most frequently used compounds which are most often polymers obtained by the polymerization of ethylene oxide or copolymers of ethylene oxide and propylene oxide. In the research presented herewith, an attempt was made to pick up those polyols not used in the drilling mud technology so far, which will ensure optimal inhibition properties of drilling fluids in a wide temperature range. This type compounds show a decrease in solubility as temperature rises, which is manifested of their aqueous solutions when becomes turbid. The cloud point of the polyol compounds depends on the salinity of the solution. For higher mineralization the cloud point temperature gets lower. The selected agents were tested in the drilling fluid compositions to confirm their inhibitory properties and to determine their influence on drilling fluid properties such as filtration and rheological parameters. The obtained research results allowed to develop an effective rock hydration inhibitor, which is characterized by efficient operation over a wide temperature range. The new agents selected based of laboratory tests may be applied in drilling mud systems in order to provide optimal inhibitory properties.

\section{Theoretical discussion}

Drilling fluids action that arrest hydration process of shale formation can be explained as diffusion process of polyglycol particles born in high temperature and salinity in to rock pores which binding polyglicol with active shale using hydrogen bonds. The polyglycol leaks into the rock pores and displaces water from them thus limit their hydration. It creates adsorption film on the rock surface as well thus limits hydration rate. An important role in the inhibition process using polyglycol is also played by $\mathrm{K}^{+}$ions due to the synergy with polyglycol (Aston and Eliot, 1994; Reid et al., 1995; Bielewicz and Bortel, 2000; Queiroz and Santos, 2000; Balaban et al., 2015; Jasiński, 2015, 2016).

Chemical compounds containing a polyether chain in their structure which is a condensation product of ethylene oxide and propylene oxide are classified as non-ionic surfactants. Such compounds may be formed as a result of the condensation of ethylene oxide and propylene oxide or their condensation with compounds having an active hydrogen atom, such as alcohols and carboxylic acids (Ogonowski and Tomaszkiewicz-Potempa, 1999).

In aqueous solutions such products obtain a weak cationic character, which is related to the possibility of hydrogen bonds creation between the oxygen atoms of ethoxy groups and water molecules. This phenomenon is also responsible for the good solubility of these compounds in water. A characteristic feature of these surfactants is the reduction of their solubility in water as temperature rising. The solubility reduction is manifested by the turbidity of their aqueous solutions and is associated with a decrease in the stability of oxonium hydroxides. The addition of electrolytes also helps to solubility reduction. The cloud point is one of the measures characterizing this type of surfactants (Ogonowski and Tomaszkiewicz-Potempa, 1999; van Oort, 2003; Villabona-Estupinan et al., 2017).

Authors of the publication (Gholami et al., 2018) define drilling muds based on glycol as "thermally activated mud emulsion" (TAME). This name refers to the mechanism of inhibitory affecting of polyglycol on active shale, which is released in the form of microdroplets under borehole conditions (temperature and salinity) and plays the role of a barrier that restricts the destructive water influence on formation. Synergy of polyglycols and their derivatives containing hydrophobic groups with $\mathrm{KCl}$ was confirmed by the authors (Villabona-Estupinan et al., 2017) in rock crumb dispersion tests and inhibition of bentonite suspensions based on measurements of their rheological parameters.

In the paper (Samaei and Tahmasbi, 2007; Khodja et al., 2010) the authors draw attention to a significant increase in the drilling rate of penetration while using a glycol based drilling mud and its excellent inhibitory properties. Another type of chemical compounds used as active shale formation hydration inhibitors may be alkoxylated glycerol derivatives (Ferreira et al., 2016). The authors of the publication indicate similar properties of these chemical compounds to polyols when used as geological formation hydration inhibitors. These compounds also present a synergy with $\mathrm{KCl}$ and the mechanism of action is the same as polyglycol. The polyglycols ability to reduce the hydration of clay formation was also confirmed by the authors (Balaban et al., 2015) by measuring the capillary suction time and swelling of clay formation. Chemical compounds being the part of polyols group as components of drilling mud may also restrain drilling induced formation fractures and support mechanical stability of the wellbore (van Oort E. et al., 1997; Taugbol et al., 2005; Zamora et al., 2013; Zhang et al., 2015; He at al., 2016; Kazemi-Beydokhti and Hajiabadi, 2018).

The authors (Xu et al., 2018; Razali et al., 2018) recommend a combination of polyglycol and nanosilica as an effective inhibitor of hydration of active shale formation. Polyglycol makes a barrier to the penetration of water on the surface of the rock, while nanosilica penetrates into the pores of rocks displacing filtrate. As solution of problem with swelling shales there is another interesting combination of polyglycols and natural rubber latex as drilling fluid components (Xu et al., 2017). The use of latex, which is a copolymer of styrene, n-butyl acrylate and 
$2 \%$ acrylic acid in a glycol drilling mud positively affects the inhibitory properties and improve lubricating properties.

The other important application of polyol compounds in drilling fluids is related to their ability to adsorb on metal surface. These chemical compounds have the ability to reduce the coefficient of friction on the metal-metal and metal-rock contact (Akram et al., 2016; Aziz et al., 2016; Luyster et al., 2016; Jasiński, 2017; Sayindla et al., 2017; Xiao et al., 2017; Zhao et al., 2017; Zhu et al., 2017; Kania et al., 2018). Propylene oxide polymers have the ability to reduce the coefficient of friction, the most effective was polypropylene glycol with the lowest molecular mass of $200 \mathrm{u}$. The authors indicate the decisive influence of the number of $\mathrm{OH}$ groups in relation to lubricating properties.

Therefore, the polymers with the lowest molecular mass due to the highest amount of $\mathrm{OH}$ groups result in the most effective reduction of the coefficient of friction. The optimal $\mathrm{pH}$ number to achieve desired lubricating properties of the drilling mud is 8 .

\section{Research on polyol's cloud point used in studies}

Six agents from the group of polyols and an emulsifier were selected for the tests. The basic properties specified by the manufacturer are listed in Table 1.

The cloud point temperature was taken in $7 \% \mathrm{KCl}$ solution which corresponds to $\mathrm{KCl}$ concentration in drilling mud. Polyol's inhibitors were added to the solution in the amounts corresponding to those used in the drilling mud compositions. For most solutions turbidity initiation was observed at $20-23^{\circ} \mathrm{C}$ already. However, for the drilling polyglycol (polglycol used in the preparation of drilling muds) and P600, the cloud point in the range of $20-95^{\circ} \mathrm{C}$ was not determined. In the case of OL2024 agent it was observed as a film on the surface of the $\mathrm{KCl}$ solution after about 15 minutes. Turbidity test results are summarized in Table 2.
Table 1. Properties of polyols used in tests

Tabela 1. Właściwości polioli użytych do badań

\begin{tabular}{|c|c|c|c|c|}
\hline $\begin{array}{l}\text { Name used } \\
\text { in the } \\
\text { paper }\end{array}$ & $\begin{array}{l}\text { Available chemical } \\
\text { structure description }\end{array}$ & $\begin{array}{l}\text { Molecular } \\
\text { mass }\end{array}$ & $\begin{array}{c}\text { Cloud Point } \\
\text { temperature } \\
\text { measured in } \\
\text { water/dibutylo- } \\
\text { glicol solution }\end{array}$ & $\begin{array}{c}\text { Cloud Point } \\
\text { temperature } \\
\text { measured in } \\
\text { water }\end{array}$ \\
\hline & & {$[\mathrm{g} / \mathrm{mol}]$} & {$\left[{ }^{\circ} \mathbf{C}\right]$} & {$\left[{ }^{\circ} \mathbf{C}\right]$} \\
\hline $\begin{array}{l}\text { Drilling } \\
\text { polyglycol }\end{array}$ & - & no data & no data & no data \\
\hline P600 & polyoxyethylen glycol, & approx. 600 & - & - \\
\hline $\mathrm{R} 2100$ & $\begin{array}{l}\text { block copolymer of ethylene } \\
\text { oxide and propylene oxide }\end{array}$ & approx. 2000 & no data & $\begin{array}{c}17-20 \\
(10 \% \text { dilution })\end{array}$ \\
\hline R2600 & $\begin{array}{l}\text { block copolymer of ethylene } \\
\text { oxide and propylene oxide }\end{array}$ & approx. 2600 & approx. 38 & $16-20$ \\
\hline OL200 & $\begin{array}{c}\text { polyoxyalkylene glycol ether } \\
\text { of fatty alcohol }\end{array}$ & approx. 680 & approx. 43 & approx. 21 \\
\hline OL2024 & $\begin{array}{c}\text { polyoxyalkylene glycol ether } \\
\text { of fatty alcohol }\end{array}$ & approx. 680 & approx. 45 & $20-24$ \\
\hline OL700 & $\begin{array}{c}\text { polyoxyalkylene glycol ether } \\
\text { of fatty alcohol }\end{array}$ & approx. 540 & approx. 56 & $20-24$ \\
\hline Emulsifier & castor-oil ethoxylate & approx. 2030 & - & - \\
\hline
\end{tabular}

Table 2. Polyols turbidity measurements results in $7 \% \mathrm{KCl}$ solution

Tabela 2. Wyniki pomiarów temperatury mętnienia polioli w 7\%-owym roztworze $\mathrm{KCl}$

\begin{tabular}{|c|c|c|}
\hline \multirow[t]{2}{*}{ Name } & \multirow[t]{2}{*}{$\begin{array}{l}\text { Available chemical } \\
\text { structure description }\end{array}$} & $\begin{array}{c}\text { Cloud Point } \\
\text { temperature measured } \\
\text { in } 7 \% \mathrm{KCl} \text { solution }\end{array}$ \\
\hline & & {$\left[{ }^{\circ} \mathbf{C}\right]$} \\
\hline drilling polyglycol $-4 \%$ & - & remains clear up to. $95^{\circ} \mathrm{C}$ \\
\hline $\mathrm{P} 600-4 \%$ & $\begin{array}{l}\text { polioxyethylen glycol, } \\
\text { also known as PEG } 12\end{array}$ & remains clear up to. $95^{\circ} \mathrm{C}$ \\
\hline R2100-4\% & $\begin{array}{l}\text { block copolymer of ethylene } \\
\text { oxide and propylene oxide }\end{array}$ & cloudy in $20^{\circ} \mathrm{C}$ \\
\hline $\mathrm{R} 2600-4 \%$ & $\begin{array}{l}\text { block copolymer of ethylene } \\
\text { oxide and propylene oxide }\end{array}$ & cloudy in $20^{\circ} \mathrm{C}$ \\
\hline OL200-4\% & $\begin{array}{c}\text { polyoxyalkylene glycol ether } \\
\text { of fatty alcohol }\end{array}$ & cloudy in $20^{\circ} \mathrm{C}$ \\
\hline OL2024-4\% & $\begin{array}{c}\text { polyoxyalkylene glycol ether } \\
\text { of fatty alcohol }\end{array}$ & cloudy in $20^{\circ} \mathrm{C}$ \\
\hline OL700 - 4\% & $\begin{array}{l}\text { polyoxyalkylene glycol ether } \\
\text { of fatty alcohol }\end{array}$ & cloudy in $20^{\circ} \mathrm{C}$ \\
\hline $\begin{array}{l}\text { R2 } 2100-3 \% \\
\text { emulsifier }-1 \%\end{array}$ & described above & cloudy in $20^{\circ} \mathrm{C}$ \\
\hline $\begin{array}{c}\text { R2 } 600-3 \% \\
\text { emulsifier }-1 \%\end{array}$ & described above & cloudy in $20^{\circ} \mathrm{C}$ \\
\hline $\begin{array}{l}\text { OL200-3\% } \\
\text { emulsifier }-1 \%\end{array}$ & described above & 23 \\
\hline $\begin{array}{l}\text { OL2024-3\% } \\
\text { emulsifier - } 1 \%\end{array}$ & described above & cloudy in $20^{\circ} \mathrm{C}$ \\
\hline $\begin{array}{c}\text { OL700-3\% } \\
\text { emulsifier }-1 \%\end{array}$ & described above & cloudy in $20^{\circ} \mathrm{C}$ \\
\hline
\end{tabular}


Since most of the agents tested showed a tendency to light turbity at low temperatures, good inhibiting properties should be expected in the temperature range $20-100^{\circ} \mathrm{C}$.

\section{Research on the inhibitory properties of drilling fluids with the addition of polyols}

The results of dispersion analysis of the Miocene shale formations (Table 3, Figures 1-3) confirm good efficiency of rock hydration inhibition for all tested drilling muds containing polyols without the addition of PHPA. Shale recovery in drilling mud reaches values close to $100 \%(\mathrm{P} 1=90-100 \%)$ at $20^{\circ} \mathrm{C}$. The $\mathrm{P}_{2}$ values of drilling muds are $65-75 \%$, where the most effective agents were OL2024 and OL200 with the addition of an emulsifier. The least effective agent $\left(\mathrm{P}_{2}=50 \%\right)$ turned out to be a drilling polyglycol. The addition of the emulsifier does not affect the dispersion values so favorably at higher temperatures. The OL2024 is the most effective without the addition of an emulsifier at $80^{\circ} \mathrm{C}$. Also OL200 shows high efficiency at this temperature. Additionally, the results of dispersion studies are documented on Figures 4-15.

Table 3. Inhibitory properties of drilling mud based on starch agent and XCD polymer, containing calcium carbonate and 7\% $\mathrm{KCl}$ with addition of $4 \%$ polyols based on measurements of Miocene shale dispersion at 20,50 and $80^{\circ} \mathrm{C}$

Tabela 3. Właściwości inhibicyjne płuczek wiertniczych na osnowie środka skrobiowego i XCD, zawierających blokator węglanowy i $7 \% \mathrm{KCl}$ z dodatkiem $4 \%$ polioli na podstawie pomiarów dyspersji łupka mioceńskiego w temperaturach 20,50 i $80^{\circ} \mathrm{C}$

\begin{tabular}{|c|c|c|c|c|c|c|}
\hline \multirow{3}{*}{$\begin{array}{l}\text { Drilling Mud Formula } \\
\text { Biocyd } \\
\text { Starch Agent } \\
\text { XCD Polymer } \\
\text { KCI } \\
\text { Calcium carbonate }\end{array}$} & \multicolumn{6}{|c|}{$\begin{array}{c}\text { Miocene shale recovery } \\
\text { after dispersion } \\
{[\%]}\end{array}$} \\
\hline & \multicolumn{2}{|c|}{$20^{\circ} \mathrm{C}$} & \multicolumn{2}{|c|}{$50^{\circ} \mathrm{C}$} & \multicolumn{2}{|c|}{$80^{\circ} \mathrm{C}$} \\
\hline & $\mathbf{P}_{1}$ & $\mathbf{P}_{2}$ & $\mathbf{P}_{1}$ & $\mathbf{P}_{2}$ & $\mathbf{P}_{1}$ & $\mathbf{P}_{2}$ \\
\hline + Drilling Polyglycol & 90 & 50 & 90 & 48 & 70 & 38 \\
\hline+ OL700 & 96 & 70 & 94 & 70 & 80 & 48 \\
\hline+ OL200 & 96 & 74 & 96 & 76 & 82 & 54 \\
\hline + OL2024 & 92 & 74 & 96 & 70 & 92 & 64 \\
\hline$+\mathrm{P} 600$ & 94 & 70 & 90 & 66 & 68 & 24 \\
\hline $\begin{array}{l}+ \text { P600 } \\
\quad \text { Emulsifier }\end{array}$ & 96 & 74 & 94 & 70 & 92 & 54 \\
\hline $\begin{array}{l}+ \text { R2100 } \\
\text { Emulsifier }\end{array}$ & 96 & 68 & 94 & 66 & 92 & 46 \\
\hline $\begin{array}{l}+ \text { OL200 } \\
\text { Emulsifier }\end{array}$ & 94 & 78 & 94 & 74 & 92 & 52 \\
\hline $\begin{array}{l}+ \text { OL2024 } \\
\text { Emulsifier }\end{array}$ & 96 & 78 & 96 & 76 & 92 & 54 \\
\hline
\end{tabular}

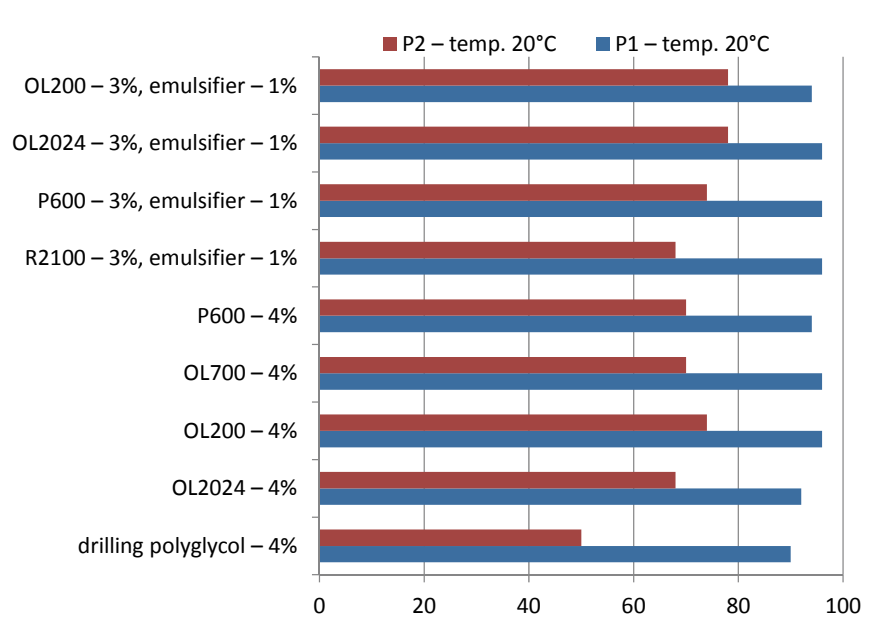

Fig. 1. Miocene shale dispersion results in the drilling muds containing various polyols at $20^{\circ} \mathrm{C}$

Rys. 1. Wyniki analizy dyspersyjnej łupka mioceńskiego w środowisku płuczek zawierających różne poliole w temperaturze $20^{\circ} \mathrm{C}$

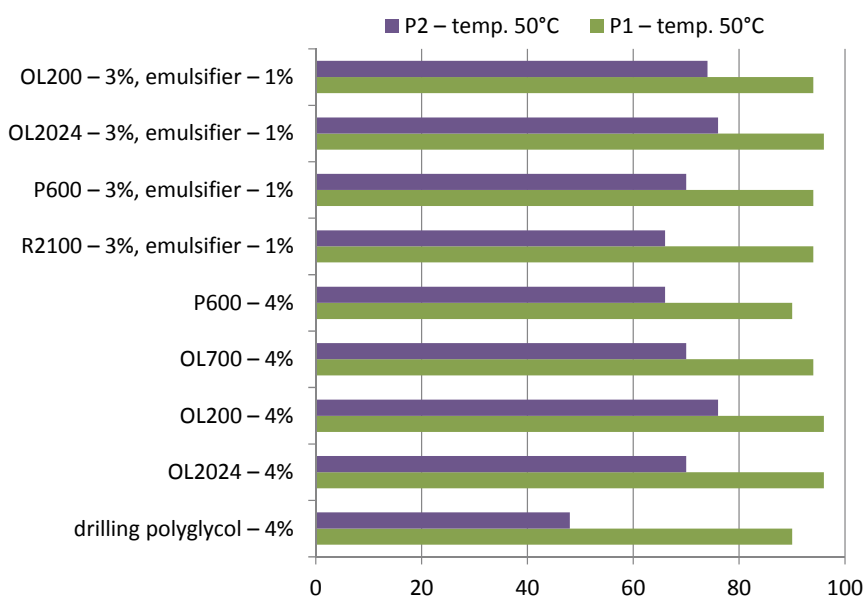

Fig. 2. Miocene shale dispersion results in the drilling muds containing various polyols at $50^{\circ} \mathrm{C}$.

Rys. 2. Wyniki analizy dyspersyjnej łupka mioceńskiego w środowisku płuczek zawierających różne poliole w temperaturze $50^{\circ} \mathrm{C}$

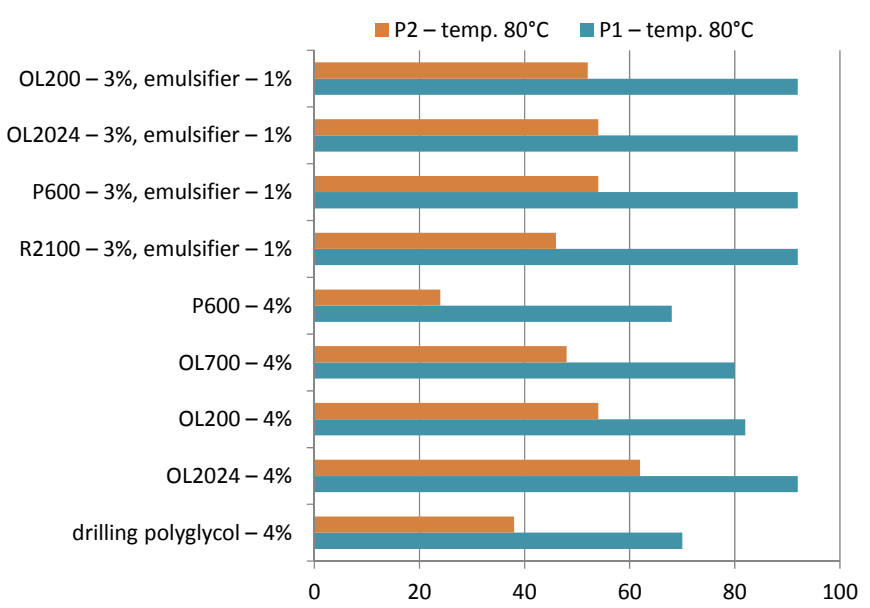

Fig. 3. Miocene shale dispersion results in the drilling muds containing various polyols at $80^{\circ} \mathrm{C}$

Rys. 3. Wyniki analizy dyspersyjnej łupka mioceńskiego w środowisku płuczek zawierających różne poliole w temperaturze $80^{\circ} \mathrm{C}$ 


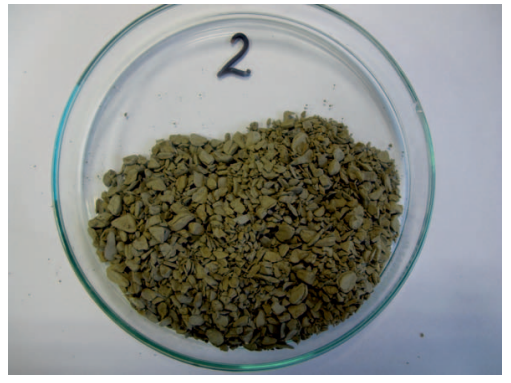

Fig. 4. Miocene shale recovery after dispersion at $80{ }^{\circ} \mathrm{C}$ in drilling mud containing 4\% OL700 (drilling mud 2, tab. 3)

Rys. 4. Odzysk łupka mioceńskiego po dyspersji w temperaturze $80^{\circ} \mathrm{C}$ w płuczce zawierającej 4\% OL700 (płuczka 2, tab. 3)



Fig. 5. Miocene shale recovery after dispersion in water at $80^{\circ} \mathrm{C}$ after earlier dispersion in drilling mud containing 4\% OL 700 (drilling mud 2, tab. 3)

Rys. 5. Odzysk łupka mioceńskiego po dyspersji w wodzie w temperaturze $80^{\circ} \mathrm{C}$ po wcześniejszej dyspersji w płuczce zawierającej 4\% OL700 (płuczka 2, tab. 3)

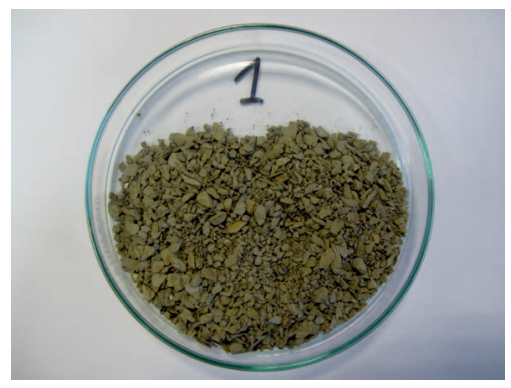

Fig. 6. Miocene shale recovery after dispersion in drilling mud at $80{ }^{\circ} \mathrm{C}$, mud containing $4 \%$ OL200 (drilling mud 3, tab. 3)

Rys. 6. Odzysk łupka mioceńskiego po dyspersji w płuczce w temperaturze $80^{\circ} \mathrm{C}$ płuczki zawierającej 4\% OL200 (płuczka 3, tab. 3)



Fig. 7. Miocene shale recovery after dispersion in water at $80^{\circ} \mathrm{C}$ after previous dispersion in drilling mud containing 4\% OL200 (drilling mud 3, tab. 3)

Rys. 7. Odzysk łupka mioceńskiego po dyspersji w wodzie w temperaturze $80^{\circ} \mathrm{C}$ płuczki zawierającej 4\% OL200 (płuczka 3, tab. 3)

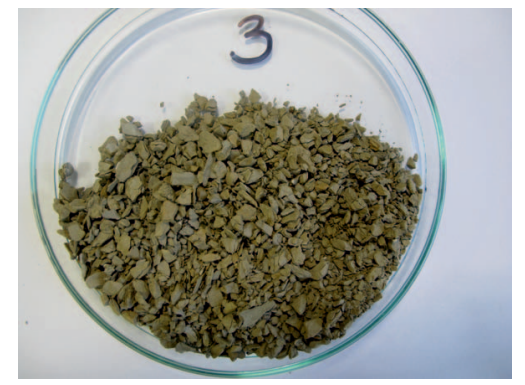

Fig. 8. Miocene shale recovery after dispersion in drilling mud at $80^{\circ} \mathrm{C}$ the drilling mud containing 4\% OL2024 (drilling mud 4, tab. 3)

Rys. 8. Odzysk łupka mioceńskiego po dyspersji w płuczce w temperaturze $80^{\circ} \mathrm{C}$ płuczki zawierającej 4\% OL2024 (płuczka 4, tab. 3)

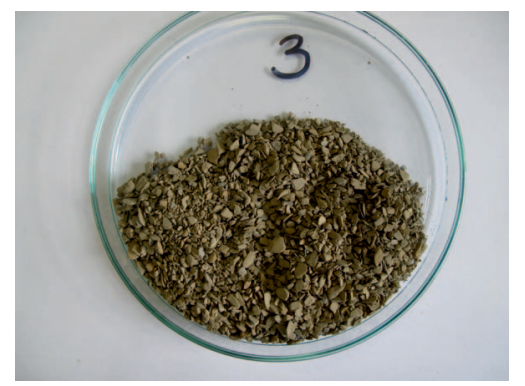

Fig. 9. Miocene shale recovery after dispersion at $80^{\circ} \mathrm{C}$ in water after previous dispersion in drilling mud containing 4\% OL2024 (drilling mud 4, tab. 3)

Rys. 9. Odzysk łupka mioceńskiego po dyspersji w wodzie w temperaturze $80^{\circ} \mathrm{C}$ płuczki zawierającej 4\% OL2024 (płuczka 4, tab. 3)

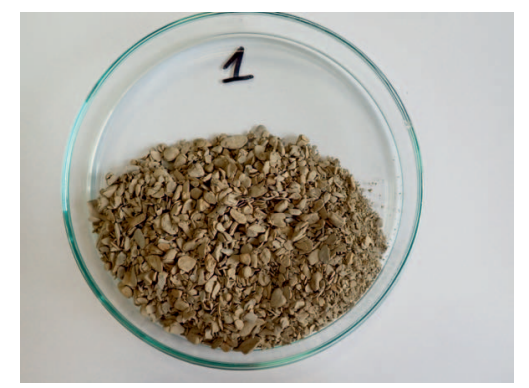

Fig. 10. Miocene shale recovery after dispersion in drilling mud at $80 \mathrm{C}$ the drilling mud containing 4\% P600 (drilling mud 5, tab. 3)

Rys. 10. Odzysk łupka mioceńskiego po dyspersji w płuczce w temperaturze $80^{\circ} \mathrm{C}$ płuczki zawierającej 4\% P600 (płuczka 5, tab. 3)



Fig. 11. Miocene shale recovery after dispersion at $80^{\circ} \mathrm{C}$ in water the drilling mud containing 4\% P600 (drilling mud 5, tab. 3)

Rys. 11. Odzysk łupkua mioceńskiego po dyspersji w wodzie w temperaturze $80^{\circ} \mathrm{C}$ płuczki zawierającej 4\% P600 (płuczka 5, tab. 3) 


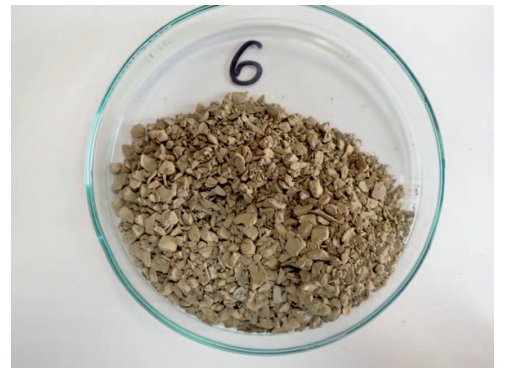

Fig. 12. Miocene shale recovery after dispersion at $80^{\circ} \mathrm{C}$ in drilling mud, the drilling mud containing 3\% R2100 and $1 \%$ emulsifier (drilling mud 7, tab. 3)

Rys. 12. Odzysk łupka mioceńskiego po dyspersji w płuczce w temperaturze $80^{\circ} \mathrm{C}$ płuczki zawierającej 3\% R2100 i $1 \%$ emulgatora (płuczka 7, tab. 3)

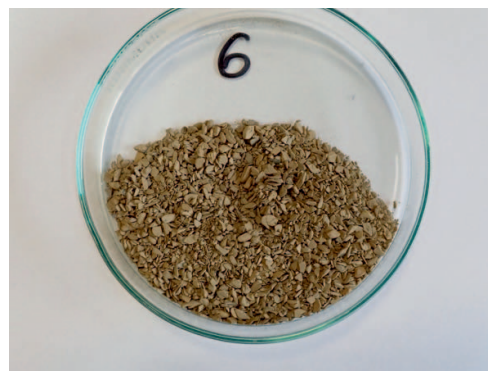

Fig. 13. Miocene shale recover after dispersion at $80^{\circ} \mathrm{C}$ in water after previous dispersion in drilling mud containing 3\% R2100 and $1 \%$ emulsifier (drilling mud 7, tab. 3)

Rys. 13. Odzysk łupka mioceńskiego po dyspersji w wodzie w temperaturze $80^{\circ} \mathrm{C}$ płuczki zawierającej 3\% R2100 i $1 \%$ emulgatora (płuczka 7, tab. 3)

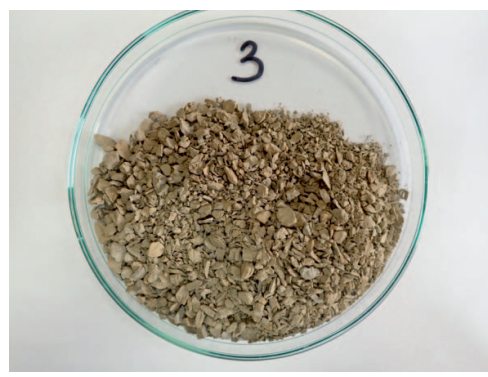

Fig. 14. Miocene shale recovery after dispersion at $80^{\circ} \mathrm{C}$ in drilling mud, the drilling mud containing 3\% OL2024 and $1 \%$ emulsifier (drilling mud 9, tab. 3)

Rys. 14. Odzysk łupka mioceńskiego po dyspersji w płuczce w temperaturze $80^{\circ} \mathrm{C}$ płuczki zawierającej 3\% OL2024 i $1 \%$ emulgatora (płuczka 9, tab. 3)

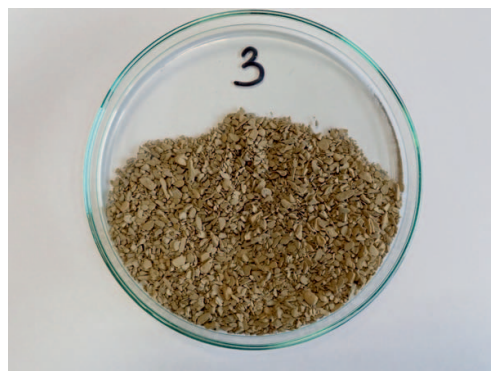

Fig. 15. Miocene shale recovery after dispersion at $80^{\circ} \mathrm{C}$ in water, the drilling mud containing 3\% OL2024 and $1 \%$ emulsifier (drilling mud 9, tab. 3)

Rys. 15. Odzysk łupka mioceńskiego po dyspersji w wodzie w temperaturze $80^{\circ} \mathrm{C}$ płuczki zawierającej 3\% OL2024 i $1 \%$ emulgatora (płuczka 9, tab. 3)
The study of changes in rheological parameters of drilling muds under the influence of temperature carried out with the OFITE 77 viscometer confirmed the stability of developed drilling muds in temperature range of $20-100^{\circ} \mathrm{C}$. The rheo-

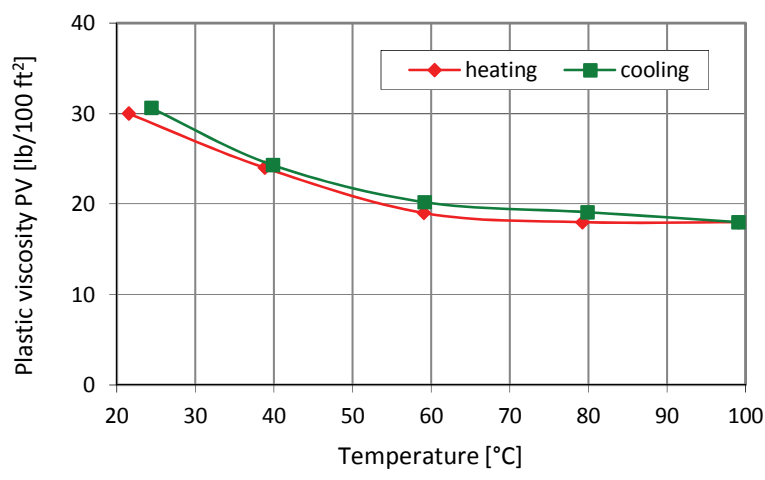

Fig. 16. Plastic Viscosity of the drilling mud with the addition of $4 \%$ OL2024 versus temperature in the range of $20-100^{\circ} \mathrm{C}$

Rys. 16. Wykres zmian lepkości plastycznej płuczki z dodatkiem $4 \%$ OL2024 w zależności od temperatury w zakresie $20-100^{\circ} \mathrm{C}$ logical parameters of the drilling muds with the addition of the selected agent OL2024 are shown graphically in the form of the Plastic Viscosity (Fig. 16) and the Yield Point (Fig. 17) against temperature graph. Polymer did not degrade

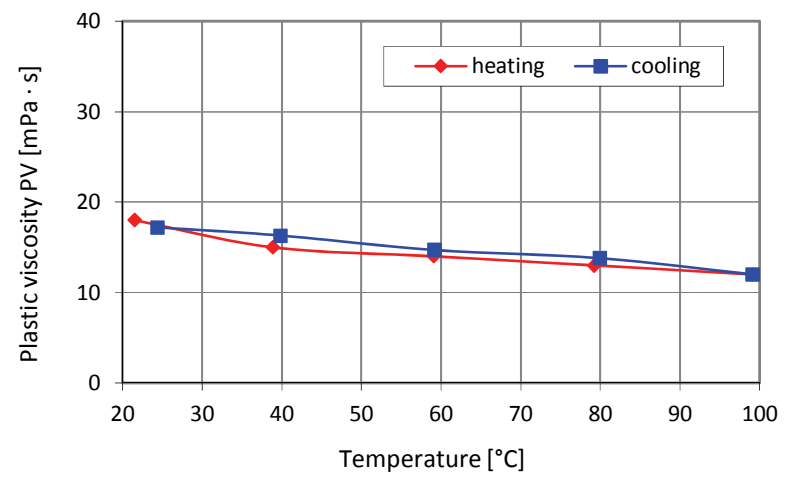

Fig. 17. Yield Point of the drilling mud with the addition of $4 \%$ OL2024 versus temperature in the range of $20-100^{\circ} \mathrm{C}$

Rys. 17. Wykres zmian granicy płynięcia płuczki z dodatkiem $4 \%$ OL2024 w zależności od temperatury w zakresie $20-100^{\circ} \mathrm{C}$ 
during test. But after cooling the rheological parameters of all drilling mud returned to their initial values and no significant differences were observed in the drilling mud heating and cooling plots. There were also no differences in the thermal stability of drilling fluids containing additives of different polyols.

\section{Conclusions}

1. Research results have allowed for the selection of new rock hydration inhibitor agents for drilling fluids which show higher efficiency than the currently used drilling polyglycol.

2. The newly developed agents are chemical compounds of the general formula $\mathrm{RO}\left(\mathrm{CH}_{2} \mathrm{CH}_{2} \mathrm{O}\right)_{\mathrm{x}}\left(\mathrm{CH}\left(\mathrm{CH}_{3}\right) \mathrm{CH}_{2} \mathrm{O}\right)_{y}$ $\mathrm{H}$, where $\mathrm{R}$ is a hydrophobic aliphatic chain derived from fatty alcohol. These agents are described in the paper as OL200 and OL2024. The first of them is a branched hydrocarbon chain and the other is a straight one. The OL200 and OL2024 agents show particularly effective performance in the area of active shale formation hydration restriction in elevated temperatures, ie. approx. $80^{\circ} \mathrm{C}$.

3. The P600, which is characterized by high efficiency at $20^{\circ} \mathrm{C}$, shows a significant decrease as the temperature rises. Similar phenomena is observed in drilling mud containing drilling polyglycol. This indicates the regularity that agents that do not have a cloud point significantly reduce their inhibition efficiency with increasing temperature. This allows to formulate hypothesis that at lower temperatures the mechanism associated with the adsorption of polyols on the surface of minerals by means of hydrogen bonds is mainly responsible for the inhibition of rock hydration. At higher temperatures there is a mechanism to create a hydrophobic barrier for water molecules by the emerging microdroplets of polyols. The use of OL2024 as a hydration inhibitor for active shale formation is optimal solution in field conditions because it shows high efficiency in a wide range of down hole temperatures. When drilling the well, at lower temperatures (up to $50^{\circ} \mathrm{C}$ ) it is advisable to add emulsifier to OL2024 in the amount of 1\% while at greater depths at higher temperatures the addition of this agent should be discontinued.

This paper was written on the basis of the statutory work entitled: Rock Hydration Inhibitor based on polyol compositions adjusted to borehole conditions - the work of the Oil and Gas Institute - National Research Institute was commissioned by the Ministry of Science and Higher Education; order number: 0016/ KW/2018, archive number: DK-4100-0016/2018.

\section{References}

Akram M.W., Meyer J.L., Polycarpou A.A., 2016. Tribological interactions of advanced polymeric coatings with polyalkylene glycol lubricant and r1234yf refrigerant. Tribology International, 97: 200-211. DOI: 10.1016/j.triboint.2016.01.026.

Aston M. S., Elliot G. P., 1994. Water based glycol drilling muds: shale inhibition mechanism. Society of Petroleum Engineers. DOI: $10.2118 / 28818-M S$.

Aziz N.A.M., Raschid U., Zulkifli N.W.M., 2016. Temperature effect on tribological properties of polyol ester-based environmentally adapted lubricant. Tribology International, 93: 43-49. DOI: 10.1016/j.triboint.2015.09.014.

Balaban R.C. de, Vidal E.L.F., Borges M.R., 2015. Design of experiments to evaluate clay swelling inhibition by different combinations of organic compounds and inorganic salts for application in water base drilling fluids. Applied Clay Science, 105-106: 124-130. DOI: 10.1016/j.clay.2014.12.029.

Bielewicz D., Bortel E., 2000. Polimers in drilling fluids technology. AGH Uczelniane Wydawnictwa Naukowo-Dydaktyczne, Kraków.

Ferreira C.C., Teixeira G.T., Lachter E.R., Nascimento R.S.V., 2016. Partially hydrophobized hyperbranched polyglycerols as non-ionic reactive shale inhibitors for water-based drilling fluids. Applied Clay Science, 132-133: 122-132. DOI: 10.1016/j. clay.2016.05.025.

Gholami R., Elochukwu H., Fakhari N., Sarmadivaleh M., 2018. A review on borehole instability in active shale formations: Interactions, mechanisms and inhibitors. Earth-Science Reviews, 177: 2-13. DOI: 10.1016/j.earscirev.2017.11.002.

He S., Liang L., Zeng Y., Ding Y., Lin Y., Liu X., 2016. The influence of water-based drilling fluid on mechanical property of shale and the wellbore stability. Petroleum, 2: 61-66. DOI: 10.1016/j. petlm.2015.12.002.

Jasiński B., 2015. Comparison of the effect of inhibited drilling muds parameters on the physical and mechanical properties of shale rocks. Nafta-Gaz, 6: 418-424.

Jasiński B., 2016. The impact of wash fluids on the quality of casing cementing after using glycol based drilling mud. Nafta-Gaz, 6: 413-421, DOI: 10.18668/NG.2016.06.04.

Jasiński B., 2017. Analysis of lubricity additives effectiveness based on research performed with the Grace M2200 drilling simulator. Nafta-Gaz, 4: 257-265, DOI: 10.18668/NG.2017.04.06.

Kania D., Yunus R., Omar R., Rashid S.A., Jan B.M., Arsanjani N., 2018. Nonionic polyol esters as thinner and lubricity enhancer for synthetic-based drilling fluids. Journal of Molecular Liquids, 266: 846-855. DOI: 10.1016/j.molliq.2018.07.014.

Kazemi-Beydokhti A., Hajiabadi S.H., 2018. Rheological investigation of smart polymer/carbon nanotube complex on properties of water-based drilling fluids. Colloids and Surfaces A, 556: 23-29. DOI: 10.1016/j.colsurfa.2018.07.058.

Khodja M., Canselier J.P., Bergaya F., Fourar K., Khodia M., Cohuat N., Benmounah A., 2010. Shale problems and waterbased drilling fluid optimization in the Hassi Messaoud Algerian oil field. Applied Clay Science, 49: 383-393. DOI: 10.1016/j. clay.2010.08.008.

Luyster M.R., Tresco K., Dobson J., Ravitz R., Eyaa Allogo C.M., Sooi Lim K., 2016. An Assessment of an Uncomplicated Drill-in Fluid and Its Application to a Wide Range of Global Completions and Their Recent Successes. Society of Petroleum Engineers. DOI: $10.2118 / 179037-\mathrm{MS}$.

Ogonowski J., Tomaszkiewicz-Potępa A., 1999. Surfactants. Wydawnictwo Politechniki Krakowskiej.

Oort E. van, Bland R.G., Roberson L., 1997. Improving HPHT 
Stability of Water Based Drilling Fliuds. Society of Petroleum Engineers. DOI: 10.2118/37605-MS.

Oort E. van, 2003. On the physical and chemical stability of shales. Journal of Petroleum Science and Engineering, 38: 213- 235. DOI: 10.1016/S0920-4105(03)00034-2.

Queiroz, J. dos Santos, R.L., 2000. Evolution of a Damaged Zone Caused by Water-Based Polymeric Drill-In Fluid. Society of Petroleum Engineers. DOI: 10.2118/58742-MS.

Razali S.Z., Yunus R., Rashid S.A., Lim H.N., Jan B.M., 2018. Review of biodegradable synthetic-based drilling fluid: Progression, performance and future prospect. Renewable and Sustainable Energy Reviews, 90: 171-186. DOI: 10.1016/j.rser.2018.03.014.

Reid P.I., Dolan B., Cliffe S., 1995. Mechanism of Shale Inhibition by Polyols in Water Based Drilling Fluids. Society of Petroleum Engineers. DOI: 10.2118/28960-MS

Samaei S.M., Tahmasbi K., 2007. The possibility of replacing oilbased mud with the environmentally acceptable water based glycol based drilling mud for the Iranian fields. Society of Petroleum Engineers. DOI: 10.2118/106419-MS.

Sayindla S., Lund B., Ytrehus J.D., Saasen A., 2017. Hole-cleaning performance comparison of oil-based and water-based drilling fluids. Journal of Petroleum Science and Engineering, 159: 49-57. DOI: $10.1016 /$ j.petrol.2017.08.069.

Taugbol, K., Svanes G., Svanes K., Omland T.H., Alteraas E., Mathisen A.M., 2005. Investigation of Flow-Back Properties of Various Drilling and Completion Fluids through Production Screens. Society of Petroleum Engineers. DOI: 10.2118/94558-MS.

Villabona-Estupinan S., Rodrigues J. de A., Nascimento R.S.V., 2017. Understanding the clay-PEG (and hydrophobic derivatives) interactions and their effect on clay hydration and dispersion: A comparative study. Applied Clay Science, 143: 89-100. DOI: 10.1016/j.clay.2017.03.021.

Xiao H., Liu S., Chen Y., Han D., Wang D., 2017. Impacts of polypropylene glycol (PPG) additive and $\mathrm{pH}$ on tribological properties of water-based drilling mud for steel-steel contact. Tribology International, 110: 318-325. DOI: 10.1016/j.triboint.2017.02.025.
Xu J., Qiu Z., Huang W., Zhao X., 2017. Preparation and performance properties of polymer latex SDNL in water-based drilling troublesome shale formations. Journal of Natural Gas Science and Engineering, 37: 462-470. DOI: 10.1016/j.jngse.2016.11.064.

Xu J., Qiu Z., Zhao X. Zhong H., Li G., Huang W., 2018. Synthesis and characterization of shale stabilizer based on polyethylene glycol grafted nano-silica composite in water-based drilling fluids. Journal of Petroleum Science and Engineering, 163: 371-377. DOI: 10.1016/j.petrol.2018.01.007.

Zamora M., Roy S., Slater K.S., Troncoso J.C., 2013. Study on the Volumetric Behavior of Base Oils, Brines, and Drilling Fluids Under Extreme Temperatures and Pressures. Society of Petroleum Engineers. DOI: 10.2118/160029-MS.

Zhang Q., Jia W., Fan X, Liang Y., Yang Y., 2015. A review of the shale wellbore stability mechanism based on mechanical-chemical coupling theories. Petroleum, 1: 91-96. DOI: 10.1016/j. petlm.2015.06.005.

Zhao X., Qiu Z., Huang W., Wang M., 2017. Mechanism and method for controlling low-temperature rheology of water-based drilling fluids in deep water drilling. Journal of Petroleum Science and Engineering, 154: 405-416. DOI: 10.1016/j.petrol.2017.04.036.

Zhu D., Jirui Hou, Qi Wei, Yuguang Chen, Kewen Peng, 2017. Development of a High-Temperature Resistant Polymer Gel System for Conformance Control in Jidong Oilfield. Society of Petroleum Engineers. DOI: 10.2118/186235-PA.

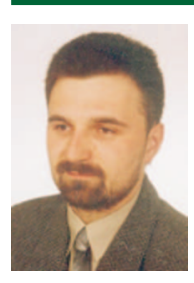

Grzegorz ZIMA Ph.D. Eng.

Assistant Professor

Department of Drilling Technology

Oil and Gas Institute - National Research Institute

25 A Lubicz St.

31-503 Krakow

E-mail: grzegorz.zima@inig.pl

\section{OFERTA BADAWCZA ZAKŁADU OCHRONY ŚRODOWISKA}

analiza zagrożeń środowiska naturalnego, związanych z dziatalnością przemysłu naftowego i gazowniczego; opracowanie i weryfikacja technologii środowiskowych w przemyśle naftowym i gazowniczym;

monitoring i badania laboratoryjne jakości środowiska (powietrza, wód i gleby) na terenach poszukiwania i eksploatacji ztóż wegglowodorów i innych terenach przemystowych;

badania laboratoryine ścieków i odpadów (w tym odpadów wiertniczych, odpadów po zabiegu hydraulicznego szczelinowania, odpadowych wód złożowych i cieczy technologicznych) oraz ocena ich potencjalnej szkodliwości dla środowiska;

klasyfikacja odpadów wydobywczych wraz ze sporządzaniem podstawowej charakterystyki odpadu; analiza zawartości rtęci w próbkach środowiskowych (stałych i ciektych), mieszaninach gazowych i materiatach przemystowych;

inwentaryzacja emisji metanu z sektora poszukiwania, wydobycia, magazynowania oraz przesyłu i dystrybucii gazu;

ocena wielkości emisji gazów cieplarnianych;

ocena jakości paliw węglowodorowych: gazu ziemnego, koksowniczego, gazów wytwarzanych w przemyśle, biogazu;

kompleksowa analiza biogazu, w tym analiza związków krzemu, chloru i fluoru;

monitoring jakości gazu ziemnego w systemie gazowniczym:

sporządzanie oraz aktualizacja kart charakterystyki substancji i mieszanin niebezpiecznych, zgodnie z obowiązujacym prawodawstwem;

obór próbek wód, ścieków, gleb, odpadów oraz gazu ziemnego, biogazu i innego typu mieszanin gazowych.

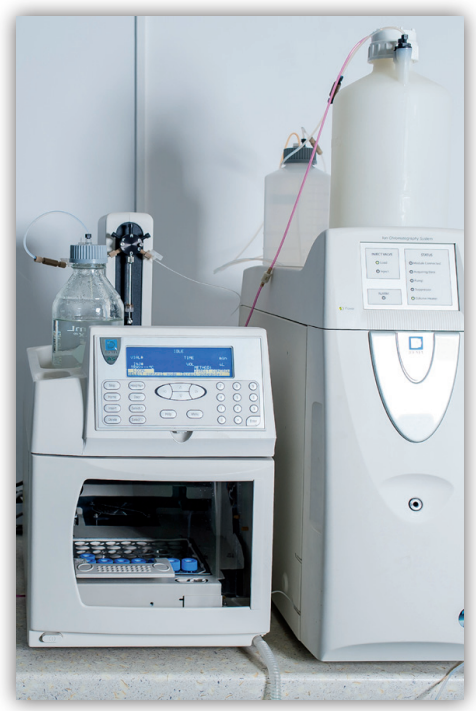

Kierownik: dr Ewa Kukulska-Zając Adres: ul. Bagrowa 1, 30-733 Kraków

Telefon: 1261774 36, 797727103 Faks: 126531665 E-mail: ewa.kukulska@inig.pl 